\title{
Monitoring the Results of the Tutoring Program in its Face-to-Face and Virtual Modalities on the Academic Achievement of Students at a Mexican University
}

\author{
Omar Cuevas Salazar ${ }^{1}$, Ramona Imelda García López ${ }^{1}$, Javier José Vales García ${ }^{1} \&$ Isidro Roberto Cruz Medina ${ }^{1}$ \\ ${ }^{1}$ Technological Institute of Sonora, Ciudad Obregón, Sonora, México \\ Correspondence: Omar Cuevas Salazar, Technological Institute of Sonora, Ciudad Obregón, Sonora, México. Tel: \\ 644-410-9000, Ext. 1722. E-mail: ocuevas@itson.edu.mx
}

Received: February 17, 2017

Accepted: March 15, 2017

Online Published: April 7, 2017

doi:10.5430/ijhe.v6n2p169

URL: https://doi.org/10.5430/ijhe.v6n2p169

\begin{abstract}
The tutorship program is aimed at supporting students throughout their university career and its objective is to prevent future problems of adaptation in the educational ambience as well as intervening in matters of academic achievement. At the Instituto Tecnológico de Sonora (Technological Institute of Sonora) (ITSON), the individual tutorship program began in 2000. In 2002 group tutoring began in order to see to the entire first year student population and today, group tutoring is offered in both the face-to-face and virtual modalities. The general objective of the present study is to determine the impact the programs of face-to-face and virtual tutoring at the ITSON has had on students' academic achievement, during the four semesters after having participated in this program. Information on 2,995 students from the different areas of study offered at the university was collected from databases which existed at the Institute and analyzed using different statistical techniques. The tutoring program is shown to have had a favorable impact on the index of students' failing classes, during the semester they were enrolled in tutoring, but not during the subsequent semesters, during which they did not participate in the tutorship program. The grade point averages obtained by students who had face-to-face tutoring were statistically different from those of the students who did not have tutoring. This was true for all of the semesters analyzed. The same thing happened with the students who had virtual tutoring except for during the second semester when the two were statistically equal.
\end{abstract}

Keywords: Face-to-face tutoring, Virtual tutoring, Adaptation to school, Students, Higher Education, Academic Achievement

\section{Introduction}

\subsection{Introduce the Problem}

Educational institutions continuously elaborate programs for students, designed to provide them with support throughout their university studies. One such program which has been enacted at most national and international institutions is the tutoring program. According to López (2006) the basis for the academic tutoring program came from the University of Oxford, where students work with an assigned tutor every week. In the United States, Canada and some European countries orientation centers are very important today. There students work with specialists in Pedagogy and Psych-pedagogy who are in close contact with the professors who are directly in charge of tutorships. These centers are an important part of institutional structure and coordinate the academic tutoring activities. Today, the newest model is tutoring assisted by computing; this technology is fundamental to learning experiences in general and specifically to the objectives related to tutorship. It has proved useful in motivating students to improve their communication, work and study skills.

But, what is tutoring? According to the definition of the Asociación Nacional de Universidades e Instituciones de Educación Superior de México (National Association of Universities and Institutions of Higher Learning of Mexico) (ANUIES) tutoring is a process of accompaniment during students' formation, with personalized attention for a student or small group of students, by competent professors, based on theories of learning more than teaching. The tutor is the professor who guides, advises and accompanies the student during his stay at the university, in order to guide him towards his integral formation, stimulating in him the ability to become responsible for his own learning and formation (ANUIES, 2001). 
Tutoring is a permanent accompanying and guiding task for a student during the follow-up of his learning and in general throughout his academic life. It is a fundamental part of the educational formation which allows for establishing an individual relationship with the student, and thus implies an individualized educational process. By means of tutoring it is possible to establish a close relationship between the professor and the student in order for the latter to be assisted, heard and guided through various aspects of his personal and academic life.

Tutoring is a task of mediation and facilitation between the professor, students and the contents of their subjects. According to García (2001), among the tutor's functions is to clear up the prerequisites for courses, and if the student has difficulties, help him solve them. On the other hand, reinforcing study content stands out, by means of discussion, questioning and clearing up questions, as well as facilitating and promoting the use of libraries, laboratories and all of the resources necessary for the student to obtain optimum formation.

Another crucial function of the tutor is to act as a link between the institutional bureaucracy and the student, it being the responsibility of the tutor to clear up any questions in this respect (Lara, 2005). The academic success of the student depends to a great measure on the efficiency of the tutor and his ability to motivate and assist the student in his various needs identified in the tutoring sessions. The result of these actions necessarily influences the results of the students' academic achievement (Duart \& Sangrà, 2000).

Lacruz (2002) comments that the tutor should favor students' achievement, considering them to be the receptors and elaborators of their knowledge and acting more as learning facilitators than as dispensers of knowledge. Along these same lines, Martínez-Guerrero and Sánchez-Sosa (1993), in a study on Mexican youth, found that the use of strategies such as text organization and programming of study activities, significantly foretells students' academic achievement. Therefore, one of the main activities in tutoring sessions is the development of strategies which contribute to facilitating the adaptation of students to their school environment in order to improve their study habits and increase their scholarly achievement.

The mission of tutoring is to prevent future problems of adapting to the educational scene, and intervening in matters of academic achievement. It attends to problems related to the end efficiency, failing, study habits, learning difficulties, anxiety towards exams, emotional stability, attitudes towards the chosen area of study and options for their trajectory, among others.

Students' academic achievement is a key indicator for educational institutions because it provides information on academic success and also allows for learning the impact which introducing innovative strategies such as tutoring have. No matter the area of study and theoretic vision assumed, it is clear that problems of academic achievement are multi-casual and are the product of students' individual characteristic and their conditions such as socio-economic inequality, and the cultural disadvantages they bring with them when entering Institutions of Higher Learning (IHL). De Los Santos (1993), De Allende (1987), Martínez (1988) and Clemente (1997), cited by the University of Guadalajara (2004) mention that, among the multiplicity of factors which affect students are:

1. Unfavorable economic conditions.

2. Deficient cultural level of the family they belong to.

3. The expectations they have in relation to education.

4. The incompatibility of the time dedicated to work and to studies.

5. The responsibilities implied by marriage.

6. Personal characteristics, for example the lack of a will to achieve.

7. Little interest of students in general, in the area of study and the institution.

Previous academic characteristics, such as low grade averages obtained in secondary education, which is reflected in insufficient knowledge and abilities upon graduation, in relation to what is required to keep up with the academic demands at the higher level.

Deficient vocational orientation before enrolling in college studies, which leads to registering in professional areas of study without basing their decision on solid information (Beltrán, 2002).

Based on all of these factors, tutoring should be carried out throughout college studies, linking authorities and people related to the educational process. Similarly, it should attend to the characteristics of each student and lead him to be responsible for his own learning.

Tutoring should attend to students who due to their academic background, family situation or level of development of study habits (among other conditions) are at risk of failing, falling behind, dropping out; and in second place, 
continuously support the rest of the student population. In order to do this previous formation and selection in tutoring and advising tasks are required for professors and advisors, so that they can jointly propose and solve significant learning problems.

\subsection{Approach to the Problem}

At the Instituto Tecnológico de Sonora (Technological Institute of Sonora) (ITSON), the individual tutoring program began in 2000 with the participation of 36 tutors and 49 students. Its purpose is to provide systemized support and guidance for students, in affective, psycho-pedagogical and socio-professional areas; so as to promote the academic and personal development, stimulate acceptance and knowledge of themselves, the construction of positive values, attitudes and habits which support school work and their integral formation through the development of a methodology of study and appropriate work for meeting the demands of their studies and promotion of participative attitudes and social abilities which promote the students' integration into the academic and socio-cultural environment. In 2002 group tutoring began to attend to the new students at the institution. In 2005, in order to increase the efficiency of the program, a methodology was established for carrying out said tutoring.

Today, at the ITSON we have the results the tutoring program in its face-to-face and virtual modalities has had on students' achievement (García, Cuevas, Vales \& Cruz, 2012a, 2012b). In these studies variables such as students' high school grade averages, points obtained on the entrance exam, whether the students have failed any subjects during the semester when they were enrolled in the tutoring program have been analyzed. However, there has been no research related to the impact that tutoring has had on the academic achievement of students after having participated in this program. That is to say, it has not been determined whether having participated in the tutoring program during their first semester has had a positive influence on students' academic achievement in subsequent semesters.

That is why we have set out to see how students have performed in the semesters after having had this tutorship, both face-to-face and virtual and whether this program has had an impact on their grades and whether the student is failing classes. Therefore, the following hypothesis is presented: face-to-face and virtual tutorship offered by the Instituto Tecnológico de Sonora, increases the percentage of passing grades and grade averages in the semesters after having participated in this program.

\subsection{Objective}

The general objective is to determine the impact the programs of face-to-face and virtual tutorship at the ITSON have on the academic achievement of our students, in the four semesters after having participated in this program.

\subsubsection{Specific objectives}

1. Determine the indexes of academic achievement for the semester during which the students took part in tutorship and for the following three semesters.

2. Identify the variables which predict improved achievement by students during the semester in which they participated in tutorship and the following semesters.

3. Determine whether there are significant differences among the semester under study, depending on the variables analyzed.

\subsection{Justification}

The aim of tutoring program at this university is to contribute to increasing students' academic achievement so that they acquire the competences and skills necessary for their professional development. The importance of this study resides in providing quantitative criteria which help evaluate the tutorship program, which in turn leads to improving the present-day program in both modalities.

\section{Theoretical Framework}

\subsection{Tutoring Program}

The main objective of implementing the tutorship programs was to raise students' academic quality through a knowledge of their skills and persons, in order to elevate their end efficiency and influence the indexes of failing, dropping out and lagging behind (Márquez, 2003).

The aim of interaction between the tutor and the tutored has the objective of incentivizing the active, critical and autonomous participation of the students within the teaching-learning process as well as providing development and study strategies and individual as well as group reflection (Prado \& García, 2009). In this respect García (2004) points out that besides impacting academic and professional areas in multiple variables associated with academic 
achievement and professional formation through tutoring, it is possible to impact the personal areas mainly associated with the family, psychological and affective problems which may affect the student's learning process and administrative processes within the university.

Within the context of higher education in Mexico, the tutoring program for undergraduate college students has gained importance over the past years as a result of the concern of these institutions about the low indexes of terminal efficiency. Faced with this concern, the idea of academic tutorship as an alternative for easing students' adaptation to the school environment and for improving their study and work habits, thus increasing the possibility of successful studies, has arisen. The proposal of tutorship programs at college level is relatively recent and brings with it a series of questions on the roles to be played by teachers and students in this scheme as pointed out by Nájera and Aguilar (2007) when they commented that educational institutions are faced with a generally unknown matter, with little theoretical, referential and practical knowledge on the subject.

\subsection{Face-to-face Tutoring}

University tutoring is understood to be a formative intervention action aimed at academic monitoring of students developed by professors as another teaching activity. Thus tutoring is the perfect space for helping a student reach efficient learning since it allows for constant monitoring of the student's progress and offers personalized guidance in function of the difficulties faced by the student. Moreover, the dialogue carried out in tutoring allows the professor to accommodate the student's expectations and interests, his previous knowledge, his degree of understanding of the subject, among other things. By means of face-to-face tutoring, the professor tries to delve into the student's knowledge, which becomes more and more exhaustive and deeper, his problems, his progress and difficulties, individual and group dynamics, and his level of aspirations in his development process (Giner, Lapeña \& Iglesias, 2008).

The tutor is a temporary companion who conscientiously helps out at certain moments along the student's route in the development of his full potential as a unique and individual being, guiding him, advising him, accompanying him or merely listening to him. He is a very important educational figure since he is a multiplier of the effort in favor of the student's personal and professional development (García-Córdoba, Trejo, Flore \& Rabadán, 2007).

The tutor's job involves establishing a conversation between professors and students on matters of scientific domain and establishing favorable attitudes towards the search for and pleasure in scientific knowledge. His function is to guide students' learning in order to achieve the objectives set down in the curriculum and at the same time to learn the causes which may be presenting the students with learning difficulties (University Teaching Center, 2007). On the other hand, he reinforces the learning material by means of discussion, questioning and clearing up problems, as well as facilitating and promoting the use of libraries, laboratories and all resources necessary for the student's obtaining optimum formation.

\subsection{Virtual Tutoring}

When tutoring is carried out by means of virtual learning media, we call it e-tutoring. Bierema and Merriam (2002, p. 219), cited by Montserrat, Gisbert and Isus (2007) define e-tutoring as "a mutual beneficial relationship between a tutor and a protege by means of a computer, which provides learning, improvement, motivation and promotion...a relationship often without limits, equalitarian and qualitatively different from tradition, face-to-face tutoring." Besides, they point out two key aspects which clearly differentiate E-tutoring from traditional face-to-face tutoring: coping with new challenges and equality in the exchange.

In this respect, Montserrat, Gisbert and Isus (2007) sum up the contributions made by Information and Communication Technologies (ICT) to e-tutoring, such as those shown in Figure 1. 


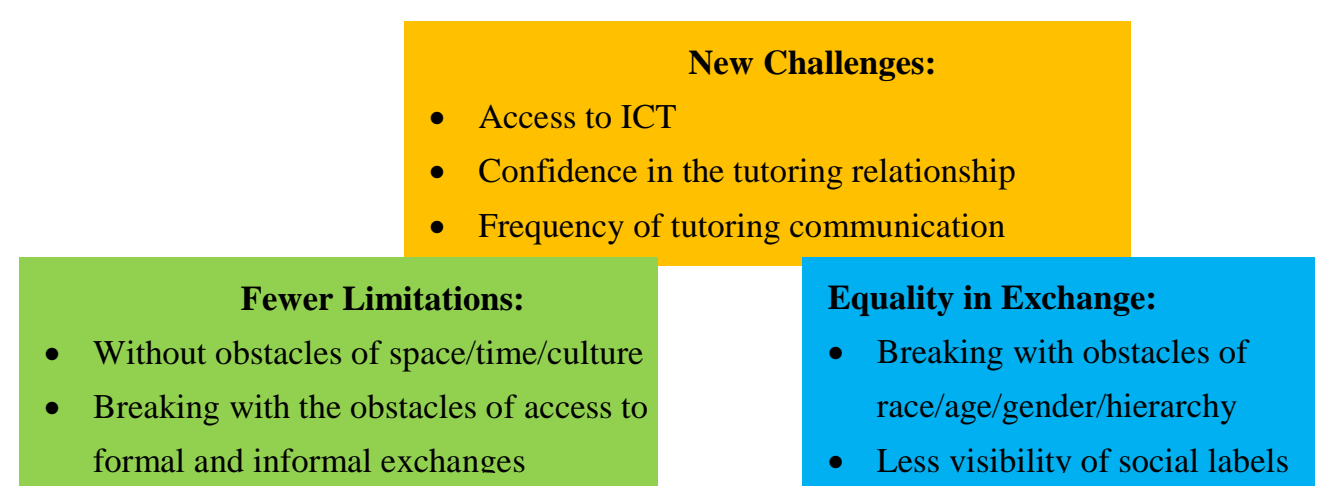

Figure 1. Contributions of ICT to tutoring

In its origins, the tutor was a prestigious authority figure who accompanied his students and guided them in their educational activities. This is perhaps the most common and widespread definition of tutoring, but progress and the development of new ICT have had the logical result of rethinking this guidance activity which centers on elucidating whether the effectiveness of university tutoring must necessarily pass through a face-to-face stage, or whether it may be carried out virtually (not face-to-face), without affecting its original character. At this point it is necessary to decide where the university of the future is going, since, based on this, one option or the other will be chosen: traditional/face-to-face or non-face-to-face/innovative. Choosing the second option would involve, without a doubt, a change in university lifestyle (Vásquez \& Mejía, 2008).

According to Maya (2003), tutoring is the permanent contact or connecting point of the student with the institution in which he is being educated, carrying out the process of academic and pedagogical feedback, facilitating and maintaining the user's motivation and supporting the learning processes involved. Virtual education facilitates student's learning at his own pace and taking into account his conditions without necessarily being subject to group processes, as happens in presence-based education. Using virtual education, the student may learn as quickly or slowly as his condition permits.

In this modality, the tutor's functions vary from academic to motivational due to the fact that in the case of students who receive e-learning it is probable they become discouraged because they do not have classmates and live tutors with whom they may share their knowledge and questions. In this case, the function of the tutor is to guide, and reduce to a minimum the student's feeling of loneliness, adding the necessary personal contact by means of feedback on the student's questions and comments. This is achieved through the use of ICT, using synchronic interaction (chats) or asynchrony activities (e-mail and on-line forums), which prove the potential of Internet in facilitating communication between people, regardless of time and space (Del Mastro, 2003).

Tutorships using virtual modes of learning put into play essential elements of the teaching-learning process: communication and knowledge. We maintain that the choice of the didactic model plays an essential role. The subjects must be given the possibility to become builders, producers of languages and meanings. This implies knowing the theories of learning and educational communication, what paradigm they maintain and how they may be later transferred to educational practice.

\subsection{Academic Achievement}

Edel (2003) posits that academic achievement and production is a level of proven knowledge in an area or subject compared to the norm for the age and academic level, so that a student's achievement can be measured by means of an evaluation process. However, simply measuring and/or evaluating the performance achieved by students does not in and of itself provide all of the guidelines necessary for action aimed at improving educational quality.

With respect to academic achievement, López, et al. (n.d., cited in Durón \& Oropeza, 1999) acknowledge the existence of four factors which considerably affect this achievement: physiological, pedagogical, psychological and sociological. Physiological factors have an important influence on poor student achievement. However, it is difficult to pinpoint to what degree since these factors are generally interacting with other factors. Together, they diminish motivation, attention and carrying out tasks, the ability to learn in the classroom and limit intellectual capacities. Pedagogical factors are those which are directly related to the quality of teaching. 
In so far as psychological factors, some students have disorder in their perception, memory and conceptualization. These malfunctions contribute to learning deficiencies. On the other hand, academic achievement is influences by variables of personality, motivation, attitude and affective factors, which relate to aspects of school level, sex and aptitudes. Finally, the sociological factors include the student's socioeconomic and family position, their level of schooling and their parents' occupation and the quality of the environment, which all significantly influence students' school achievement.

Given that the main objective of all educational institutions is for students to achieve high levels of achievement, tutorship programs become one of the fundamental strategies to this end, corresponding to the new vision of higher education, since the purpose of these programs is to potentiate the integral formation of the student with a humanist, responsible vision in the face of the needs and opportunities of the development of Mexico. Besides, without a doubt, it constitutes a very valuable resource for easing the student's adaptation to the school environment, improving his study and work skills in a timely manner, fighting the indexes of failing and scholastic backlog, decreasing the rates of drop-outs and improving the end efficiency by attending to specific problems in the study route of each student in each academic institution (University of Guadalajara, 2004).

Through tutoring the students' formative development is strengthened and the development of the intellectual skills necessary for improving their academic achievement is stimulated. The latter is reflected in the decrease of indexes of students' lagging behind in their studies, in an increase in levels of end efficiency and the improvement of students' grade averages.

Students' academic success to a great degree depends on the efficiency of the tutor and his capacity to motivate the student, attending to his various needs identified in the tutoring sessions. The result of these actions necessarily influences the results of students' academic achievement (Vales, 2009).

Therefore, an evaluation of the impact tutoring has on academic achievement is of upmost importance given the fact that by means of tutoring it may be determined whether the tutoring program is satisfying the main objective which, according to ANUIES (2001), are related to the issue of solving problems related to students' academic achievement.

\section{Methodology}

\subsection{Participants}

In order to evaluate whether the tutoring program had a positive impact during the semester when it was given and during subsequent semesters, we used the data from a class of students during their first four semesters. The students were to participate in the tutoring program during their first semester. In the study a total of 2,995 students from different areas of undergraduate study offered by the Institute participated. The ages of the students varied, but the majority was between 17 and 19 years old; males and females participated indiscriminately.

\subsection{Design}

The focus used in the present research was quantitative, which is used in studies where data is collected and analyzed in order to prove a previously established hypothesis. It is based on the use of statistics in order to establish the patterns of behavior of a given group. The design method is quasi-experimental since the students were not assigned at random to the groups (Hernández, Fernández \& Baptista, 2010), but rather each student registered with the tutor of their choice.

In order to evaluate the impact of face-to-face and virtual tutoring on the academic achievement of students during the semester in which they took the tutoring course and during the subsequent semesters, the students' grade point averages were used for these semesters, and information on whether they failed a class or not. The variables of prediction of academic success which were registered were: a) student's grade average from high school, b) points on the verbal skills section of the entrance exam, c) points on the numerical skills section on the entrance exam, d) gender, and e) whether the student took the tutoring course or not. The variables described were analyzed using the SPSS statistics pack.

\subsection{Procedure}

We requested from the Coordination of Academic Development the data for students who took the face-to-face and virtual tutoring courses. The data on the academic indicators such as students' high school averages, points on verbal and reasoning and average grades for the first four semesters which are the object of this study were requested from the Department of School Registration, the official entity which safeguards students' grades at the Institute. Both data bases were combined and purged, eliminating incomplete or illogical registrations.

The effects of both modalities of tutoring using statistical analysis of the data was carried out in the following order: 
A description of the data was carried out and the measurements of the central tendency and dispersion of the variables of the study were found. To analyze the dependence among variables 'participated in tutoring' and 'gender' the appropriate techniques for this type of data were used, that is, categorical data analysis, since these variables are in the classification order (Agresti, 1990). Categorical data analysis consists of analysis of the dependence between the classification variables by means of the chi-squared test.

The effect and the possible dependency of the variables of 'prediction of school success' and 'students' average grades' was determined using multiple regression and logistic regression analysis, for each of the four semesters. For logistic regression analysis, the dependence may be explained in terms of the probability and odds ratios or opportunity analysis (Hosmer \& Lemeshow, 2000).

Analysis of variance was used to determine whether there was a statistical difference of the grade point averages of students who did not receive tutoring, students who received face-to-face tutoring and students who received virtual tutoring. This was studied for each of the students' four semesters under study. Analysis of variances is a statistic technique used to compare three or more sample measures. It produces an $\mathrm{F}$ reason, whose numerator represents the variation between the groups compared and the denominator contains an estimate of the variation within the groups. The F Distribution factor indicated the magnitude of the differences between groups in relation to the magnitude of the variation within each group. The higher the $\mathrm{F}$ factor, the greater the probability of rejection of the null hypothesis of the equality of medians (Levin, 1999).

\section{Results}

In order to achieve better organization and understanding of the results, they are presented based on each of the specific objectives postulated:

Objective 1. To determine the indexes of academic achievement for the semester during which the student received tutoring and for the three subsequent semesters.

The analysis of the results began with a description of the data presented in Table 1, where $\mathrm{S}$ (zero for female and one for male) is the gender of the student, $\mathrm{P}$ is the average obtained in high school, $\mathrm{RV}$ is the points on verbal reasoning, RN is the points on numerical reasoning; the last two variables are obtained from the entrance exam; PSEM1, PSEM2, PSEM3and PSEM4 are the student's grade point average for each semester; RSEM1, RSEM2, RSEM3 and RSEM4 indicate whether a student failed at least one subject during the semester; T (zero if the student had no tutoring and one if he had either of the two modalities of tutoring) indicate whether he had tutoring or not.

The variables of gender (S), and tutoring (T) if he failed at least on subject (RSEM1, RSEM2, RSEM3 and RSEM4) are coded with ones and zeros. The measurements of S and T for example, are interpreted in the sense that $49 \%$ of the students were male and $43 \%$ of the students had tutoring in either of its modalities. Considering that it is obligatory for students to have tutoring during their first semester, this percentage is low.

Of the four semesters studied, the highest percentage of students' failing at least one subject was during the fourth semester (RSEM4) with 53\% and the semester in which fewest students failed at least one subject was the second semester (RSEM2) with $43 \%$.

The letter $n$ indicated the number of students who participated in each semester. A total of 2,995 students registered in the first semester and of these 2992 finished the semester. The number of students considered in the second semester was 2706, eliminating those who dropped out or did not register; for the third semester 2537 students were taken into account and for the fourth semester 2416. 
Table 1. Description of the variables involved in the study

\begin{tabular}{lccccc}
\hline & $n$ & Minimum & Maximum & Median & Standard Deviation \\
\hline$P$ & 2986 & 6.00 & 10.0 & 8.24 & 0.79 \\
$R V$ & 2995 & 200 & 749 & 473.15 & 89.19 \\
$R M$ & 2995 & 268 & 800 & 517.25 & 98.71 \\
$P S E M I$ & 2992 & 0 & 10.00 & 7.81 & 2.00 \\
$P S E M 2$ & 2706 & 0 & 10.00 & 7.75 & 2.02 \\
$P S E M 3$ & 2537 & 0 & 10.00 & 7.39 & 2.02 \\
$P S E M 4$ & 2416 & 0 & 10.00 & 7.18 & 2.19 \\
$R E S E M 1$ & 2992 & 0 & 1 & 0.48 & 0.50 \\
$R E S M 2$ & 2706 & 0 & 1 & 0.43 & 0.49 \\
$R E S M 3$ & 2537 & 0 & 1 & 0.52 & 0.50 \\
$R E S E M 4$ & 2416 & 0 & 1 & 0.53 & 0.50 \\
$S$ & 2995 & 0 & 1 & 0.49 & 0.50 \\
$T$ & 2995 & 0 & 1 & 0.43 & 0.50 \\
\hline
\end{tabular}

Table 2 presents a description of the tutoring variable in which students are classified by gender. This table shows that out of 2,995 students, a total of 1,706 (57\%) did not have tutoring (NT); 1,226 (40.9\%) had face-to-face tutoring (TP); and $63(2.1 \%)$ had virtual tutoring (TV). Out of the total number of students $52 \%$ had no tutoring, $45.5 \%$ had face-to-face tutoring and $2.5 \%$ had virtual tutoring.

In Table 2 shows that, $46.2 \%$ of the females had no tutoring, while $53.8 \%$ of the males had no tutoring. $56.2 \%$ of the females had face-to-face tutoring and $43.8 \%$ of the males had the same kind of tutoring. $60.3 \%$ of the females had virtual tutoring and of the males $39.7 \%$ had this modality. The chi-squared test was used to determine whether there was dependence between the variables 'had tutoring' and 'gender' and this proved highly significant. This indicates that having tutoring depends on the student's gender. This shows that more females than males had tutoring in either of its modalities.

Table 2. Classification of students based on their tutoring (had no tutoring, had face-to-face or virtual tutoring) and gender (Females and males)

\begin{tabular}{|c|c|c|c|c|c|c|}
\hline & & & $N T$ & $T P$ & $T V$ & Total \\
\hline \multirow[t]{9}{*}{ Gender } & Female & Number & 788 & 689 & 38 & 1515 \\
\hline & & $\%$ Row & $52.0 \%$ & $45.5 \%$ & $2.5 \%$ & $100.0 \%$ \\
\hline & & $\%$ Column & $46.2 \%$ & $56.2 \%$ & $60.3 \%$ & $50.6 \%$ \\
\hline & & $\%$ Total & $26.3 \%$ & $23.0 \%$ & $1.3 \%$ & $50.6 \%$ \\
\hline & Male & Number & 918 & 537 & 25 & 1480 \\
\hline & & $\%$ Row & $62.0 \%$ & $36.3 \%$ & $1.7 \%$ & $100.0 \%$ \\
\hline & & $\%$ Column & $53.8 \%$ & $43.8 \%$ & $39.7 \%$ & $49.4 \%$ \\
\hline & & $\%$ Total & $30.7 \%$ & $17.9 \%$ & $.8 \%$ & $49.4 \%$ \\
\hline & Total & Number & 1706 & 1226 & 63 & 2995 \\
\hline
\end{tabular}

Finally the average grades of students in the three groups of the study are observed: 1) those who had no tutoring, 2) those who had face-to-face tutoring and, 3) those who had virtual tutoring. This includes grades for all four semesters under study and for the average grades of high school (see Figure 2). 


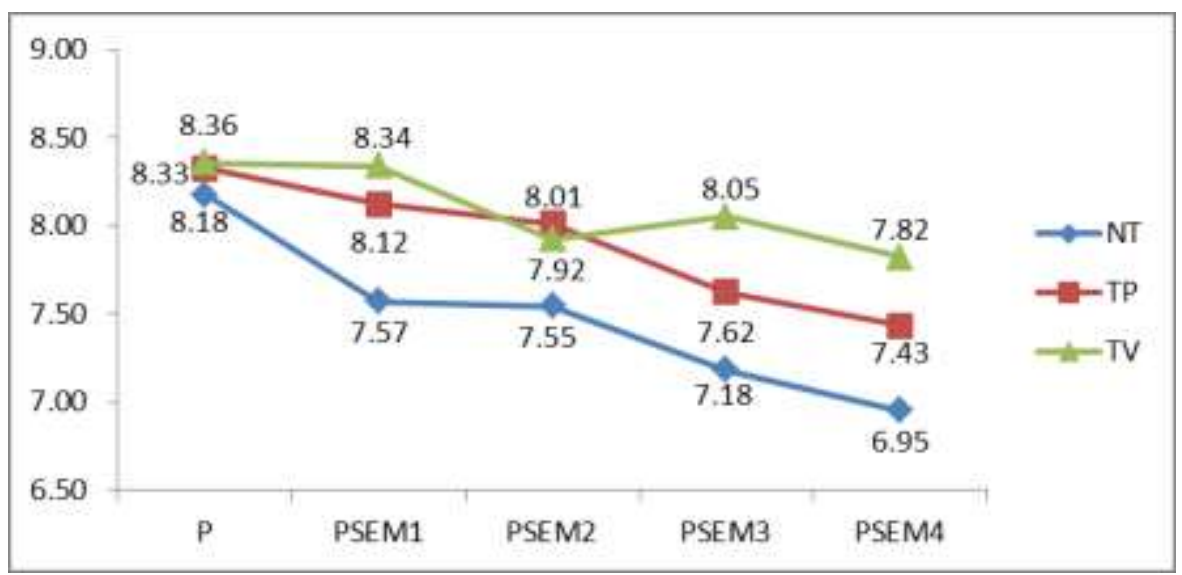

Figure 2. Averages of high school grades $(\mathrm{P})$ and the four semesters under study, for the students who did not have tutoring (NT), those who had face-to-face tutoring (TP) and those who had virtual tutoring (TV).

As may be observed in Figure 2, regardless of the group, the average grades of students decreases with each semester, which is clear evidence that the student requires tutoring in subsequent semesters. The average grades for students who had no tutoring are lower than those for students who had tutoring in either of its modalities. This is true in each of the four semesters of the study, as well as for average high school grades.

Objective 2. To identify the variable which best predicts students' achievement during the semester when they had tutoring and the subsequent semesters.

For this objective multiple regression analysis was carried out in order to identify the most important variables for explaining the average grades of students in each of the four periods of the study. The results of the analysis are shown in Table 3. The variables are placed from one to five. Variable one best explains and variable five is the one which least explains the behavior of the average grades for the semester analyzed. The variables which appear were significant. That is, different from zero; their value appears in the coefficient. The model of regression for the variable of average grades (PAD06) would be:

$$
P A D 06=1.629+0.524 P+0.004 R N+0.373 T-0.332 S
$$

This equation is interpreted in the following way: every point increase in the average of high school grade is equivalent to an increase of 0.524 points in the average of the first year of university; for every 100 points increase in the points for numerical reasoning, there is an increase of 0.4 points in the grade averages; having face-to-face tutoring, on average increases the grade average 0.373 points for the semester being studied. Females have, on average, 0.332 points more than males. In the first semester of studies, the points for verbal reasoning have no influence on grade point averages. Also $\mathrm{R}^{2}=0.124$ was obtained, meaning that the model with these four variables explains the $12.4 \%$ of the grade average obtained during the first semester of studies.

In Table 3 it can be observed that the tutoring variable $(T)$ helps better explain the behavior of grade point averages, in the semester during which tutoring is taking place and explains less so in the following three semesters. To the contrary, the gender variable $(S)$ better explains the grade averages for the semester being studied for the third and fourth semesters, than for the first two semesters. Finally, for the four semester, the variable which best explains this is the high school average $(P)$.

Table 3. Variables which help explain the behavior of grade point averages during the semester being studied, using multiple linear regression

\begin{tabular}{lcrrrrrr}
\hline & $\begin{array}{c}\text { Constant } \\
\text { value }\end{array}$ & Variable 1 & Variable 2 & Variable 3 & Variable 4 & Variable 5 & $\mathrm{R}^{2}$ \\
& & & & & & \\
\hline PSEM1 & 1.629 & $0.524 \mathrm{P}$ & $0.004 \mathrm{RN}$ & $0.373 \mathrm{~T}$ & $-0.332 \mathrm{~S}$ & & 0.124 \\
PSEM2 & 0.993 & $0.588 \mathrm{P}$ & $0.003 \mathrm{RN}$ & $-0.525 \mathrm{~S}$ & $0.231 \mathrm{~T}$ & $0.001 \mathrm{RV}$ & 0.141 \\
PSEM3 & 1.272 & $0.598 \mathrm{P}$ & $-0.808 \mathrm{~S}$ & $0.003 \mathrm{RN}$ & $0.264 \mathrm{~T}$ & & 0.152 \\
PSEM4 & 0.530 & $0.665 \mathrm{P}$ & $-0.808 \mathrm{~S}$ & $0.003 \mathrm{RN}$ & $0.277 \mathrm{~T}$ & & 0.155 \\
\hline
\end{tabular}


In order to model the variable dependent of failing (in which 1 is failed and 0 is did not fail), we used logistic regression. The independent variables were: high school average, points obtained on the section of numerical reasoning, points obtained on the section of verbal reasoning, tutoring and gender. Table 4 shows the information for each of the four semesters under study. All of the coefficients obtained were significant, that is different from zero. The logistic regression model for the variable 'failed during the first semester' (RSEM1), expressed in terms of probability (Prob) would be as follows:

$$
\operatorname{Prob}\{R S E M 1\}=\frac{1}{1+e^{-z}}
$$

Where $Z=8.379-0.790 P-0.004 R N-0.296 T+0.525 S$

That means that the variable 'failed' depends on the average of high school grades, the points on numerical reasoning on the entrance exam, tutoring and student's gender. If the student has a grade point average of 7 in high school, obtained 600 points on numerical reasoning, did not have tutoring and is a female, the probability of failing would be:

$$
\operatorname{Prob}\{R S E M 1\}=\frac{1}{1+e^{-8.379+0.790 * 7+0.004 * 600+0.296 * 0-0.525 * 0}}=\frac{1}{1+e^{-0.449}}=0.61
$$

The probability that a student with the same charactersitics, but having had tutoring fails would be:

$$
\operatorname{Prob}\{R S E M 1\}=\frac{1}{1+e^{-8.379+0.790 * 7+0.004 * 600+0.296 * 1-0.525 * 0}}=\frac{1}{1+e^{-0.153}}=0.54
$$

The probability of failing while having tutoring is less than for failing without having tutoring. The opportunity ratio for two students who failed, where one did not have tutoring and the other did have face-to-face monitoring would be:

$$
\frac{0.61}{0.54}=1.13
$$

That is to say, the probability of a student who has not had tutoring failing is 1.13 times greater than for the student who has had face-to-face tutoring.

Table 4. Variable which help explain the behavior of the variable 'fail' during the semester studied, using the model of logistic regression

\begin{tabular}{lcccccc}
\hline & Constant & Variable & Variable & Variable & Variable & $\mathrm{R}^{2}$ \\
& Value & 1 & 2 & 3 & 4 & Cox \& Snell \\
\hline RSEM1 & 8.379 & $-0.790 \mathrm{P}$ & $-0.004 \mathrm{RN}$ & $-0.296 \mathrm{~T}$ & $0.525 \mathrm{~S}$ & 0.147 \\
RSEM2 & 6.017 & $-0.640 \mathrm{P}$ & $-0.001 \mathrm{RV}$ & $-0.002 \mathrm{RN}$ & $0.626 \mathrm{~S}$ & 0.100 \\
RSEM3 & 3.924 & $-0.462 \mathrm{P}$ & $-0.002 \mathrm{RV}$ & $0.754 \mathrm{~S}$ & & 0.080 \\
RSEM4 & 4.305 & $-0.509 \mathrm{P}$ & $-0.002 \mathrm{RN}$ & $0.003 \mathrm{~S}$ & & 0.089 \\
\hline
\end{tabular}

In Table 4 it may be observed that the variable 'tutoring' appears in the semester where it was taken; that is, it has an effect on the variable 'fail', but not in the semesters after having had it. Thus, it may be deduced that failure does not depend on whether or not there was tutoring, after having finished the tutoring program.

Objective 3. To determine if there are significant differences among the semesters which are the object of this study, based on the variables analyzed.

Variance analysis was carried out to see whether students' grade averages were the same for each of our three groups under study (those who did not have tutoring, those who had face-to-face tutoring and those who had virtual tutoring). This analysis was carried out in each of the four semesters, resulting significant in all cases (see Table 5). This indicated that the grade averages for students who did not have tutoring and those who had either of its modalities are different, for the four semester, proving the differences shown in figure 2 to be statistically significant. The difference between the averages of the three groups analyzed is more evident when the student begins his undergraduate studies. 
Table 5. Analysis of variance for grade averages with tutoring (NT, TP and TV) for the four semester of the study

\begin{tabular}{ccccccc}
\hline & & SC & Df & CM & F & Sig \\
\hline \multirow{2}{*}{ PSEM1 } & Among groups & 237.879 & 2 & 118.940 & 30.380 & 0.000 \\
& Within groups & 11703.319 & 2989 & 3.915 & & \\
& Total & 11940.199 & 2991 & & & \\
\hline \multirow{2}{*}{ PSEM2 } & Among groups & 142.883 & 2 & 71.442 & 17.733 & 0.000 \\
& Within groups & 10889.850 & 2703 & 4.029 & & \\
& Total & 11032.733 & 2705 & & & 0.000 \\
\hline \multirow{2}{*}{ PSEM3 } & Among groups & 145.592 & 2 & 72.796 & 16.934 & \\
& Within groups & 10893.415 & 2534 & 4.299 & & 0.000 \\
& Total & 11039.007 & 2536 & & & \\
\hline \multirow{2}{*}{ PSEM4 } & Among groups & 156.923 & 2 & 78.462 & 16.495 & \\
& Within groups & 11478.157 & 2413 & 4.757 & & \\
& Total & 11635.080 & 2415 & & & \\
\hline
\end{tabular}

A comparison of the t-tests of the three groups was carried out, for each one of the periods under study. The comparisons NT vs TP, NT vs TV and TP vs TV were carried out. The P-values appear in Table 6. In all of the cases which were compared the grade averages for students who did not have tutoring was significantly different from that of the students who had had tutoring. Upon comparing the grade averages of students who did not have tutoring with those who had virtual tutoring, for two periods, the results were statistically equal, in high school and in the second semester (SEM2), with an $\alpha=0.05$. In all cases, the grade averages for those students who did have face-to-face tutoring was statistically equal to those who had virtual tutoring.

Table 6. P-values for the comparisons of the three groups, for each of the three periods studied

\begin{tabular}{cccc}
\hline & NT vs TP & NT vs TV & TP vs TV \\
\hline High School & $<0.0001$ & 0.078 & 0.615 \\
SEM1 & $<0.0001$ & 0.004 & 0.356 \\
SEM2 & $<0.0001$ & 0.165 & 0.724 \\
SEM3 & $<0.0001$ & 0.003 & 0.114 \\
SEM4 & $<0.0001$ & 0.005 & 0.182 \\
\hline
\end{tabular}

Besides, variance analysis was made to measure the equality of the high school average in each of the three groups studied and it proved significant with an $\alpha=0.05$, thus there are differences among the three groups analyzed. That is, students who had tutoring during the first semester of undergraduate studies had a better grade point average in high school than students who did not have tutoring. From these results it may be said that the students who chose the programs and benefits offered by the university, such as tutoring, are those students who had better grade point averages in high school. Therefore, the grades in the semester when tutoring is taken may be due to the tutoring program, the previous academic achievement of the student or both.

\section{Conclusions}

The tutoring program shows a favorable impact on the index of students' failing classes, during the semester they are having tutoring, but not during the subsequent semesters, during which they did not participate in the tutoring program.

Having analyzed the data, we were unable to determine the effect of tutoring on students' grade point averages, during the semester they were having tutoring and the subsequent semesters. This effect may also be due to the previous academic achievement acquired by students, measured by their grade averages. With this result, it is feasible to think that students with the best academic achievement take advantage of the programs the university has to offer.

In a study in California, Glass and Garett (1995, as cited in Rigalt, n.d.) found that educational guidance programs during the first year of studies promotes and improves students' achievement regardless of age, gender, race, social 
level or average income. Likewise, studies carried out by García, Cuevas, Vales and Cruz (2012a, 2012B) show the positive effect of tutoring during the semester that tutoring is going on, in which the probability rate of a student who is not having tutoring failing is more than twice that of a student who is having tutoring.

Other research such as that of Hernández, Martínez and Carranza (2013) pose the idea that according to the application of the Institutional Tutoring Program which supports the actions of educational intervention at the University of Guanajuato, there was a decrease in the index of failing grades of $22.72 \%$, with respect to the total number of students enrolled in a semester after having implemented the program. Thus tutorships are an alternative which may contribute to a decrease in the indexes of failing grades and school dropout.

On the other hand, López (2009) mentions that tutoring plays a very important role in the process of a student's formation during his stay at the university. The student perceives it as a fundamental figure for him from the academic point of view, but the job of the tutor is not limited to academic activities, but must promote and generate the integral development of the student.

Finally, the grade point average in high school is the variable which best explains the behavior of the grade averages during the semester of study. This behavior was repeated for the four semesters which were analyzed. The points obtained on the numerical section, the gender of the students and tutoring are variables which also help explain students' grade averages. Tutoring best explains behavior during the semester in which the student has tutoring.

The grade point averages obtained by students who had face-to-face tutoring were statistically different from those of the students who did not have tutoring. This was true for all of the semesters analyzed. The same thing happened with the students who had virtual tutoring, except for during the second semester when the two were statistically equal.

Likewise, high school grade point averages was the variable which best explains the behavior of the 'fail' variable and this is repeated for all of the semesters analyzed. Tutoring only appears in the semester in which it is given.

It is recommended analyzing other research in which different instruments allow for evaluating the impact this program has on students' grade point averages in the semesters following their participation in the tutoring program.

\section{References}

Agresti, A. (1990). Categorical data analysis. USA, John Wiley \& Sons.

ANUIES. (2001). Programas Institucionales de Tutoría. México: ANUIES

Beltrán, C. J. \& Suárez, D. (2002). El quehacer tutorial. Guía de trabajo. México: Universidad Veracruzana.

Del Mastro, C. (2003). El aprendizaje estratégico en la educación a distancia. Perú: G.

Duart, J. \& Sangrà, A. (2000). Aprender en la virtualidad. España: Gedisa.

Durón, T. L. \& Oropeza, T. R. (1999). Actividades de estudio: análisis predictivo a partir de la interacción familiar y escolar de estudiantes de nivel superior. Documento de trabajo, Facultad de Psicología, México, UNAM.

Edel, R. (2003). El rendimiento académico: concepto, investigación y desarrollo. REICE. Revista Electrónica Iberoamericana sobre Calidad, Eficacia y Cambio en Educación, $1(2)$. http://www.ice.deusto.es/RINACE/reice/vol1n2/Edel.pdf

García, L. (2001). La Educación a Distancia. De la Teoría a la Práctica. Barcelona, España: Ariel Educación.

García-Córdoba, F., Trejo, M. R., Flores, L. y Rabadán, R. (2007). Tutoría. Una estrategia educativa que potencia la formación de profesionales. México: Ed. Limusa.

García, R. I., Cuevas, O., Vales, J. J. y Cruz, I. (2012a). Impacto del Programa de Tutoría en el desempeño académico de los alumnos del Instituto Tecnológico de Sonora. Revista Electrónica de Investigación Educativa, 14(1), 106-121. http://redie.uabc.mx/vol14no1/contenido-garciaetal.html

García, R. I., Cuevas, O., Vales, J. J. \& Cruz, R. (2012b). Impacto de la tutoría presencial y virtual en el desempeño académico de alumnos universitarios Revista Iberoamericana de Educación, No. 58 /2. http://www.rieoei.org/deloslectores/4497Garcia.pdf

Giner, A., LaPeña., C. \& Iglesias, M. (2008). La acción tutorial en la universidad de Alicante del espacio europeo de educación superior. Seminario internacional: La acción tutorial en la universidad del siglo XXI (pp. 1-9). España: Universidad de Alicante.

Hernández, R., Fernández, C. \& Baptista, P. (2010). Metodología de la investigación (Quinta edición). México: 


\section{McGrawHill}

Hernández, Y; Martínez, J. \& Carranza, C. (2013). Programa Institucional de Tutorías: Una estrategia para elevar el nivel de aprovechamiento en una institución educativa. Revista Acta Universitaria, 23(1), 31-36. http://www.redalyc.org/articulo.oa?id=41626112005

Hosmer D. W. y Lemeshow S. (2000). Applied logistic regression. USA: John Wiley \& Sons. https://doi.org/10.1002/0471722146

ITSON (2009). Programa de tutoría. http://www.itson.mx/tutoria/modulos.htm

Lacruz, M. (2002). Nuevas tecnologías para futuros docentes. España: Universidad de Castilla-La Mancha.

Lara, R. (2005) El aprendizaje cooperativo: un modelo de intervención para los programas de tutoría escolar. Revista de la Educación Superior, 133, 8-25.

Levin, J. (1999). Fundamentos de Estadística en la Investigación Social. México: Oxford University Press.

López, D. (2006). Tutoría, modalidad para los docentes del CBTIS no. 8. http://www.uaeh.edu.mx/docencia/Tesis/icshu/licenciatura/documentos/Tutoria,\%20modalidad.pdf

López, J. (2009). La percepción del alumno ante la tutoría. Revista Cuadernos de Educación y Desarrollo, 1(4). http://www.eumed.net/rev/ced/04/lbj.htm

Márquez, L. (2003). Evaluación de un programa de tutoría académica a nivel licenciatura por tutores y estudiantes. (Tesis) Instituto Tecnológico de Sonora.

Martínez-Guerrero, J. \& Sánchez, J. J. (1993). Estrategias de aprendizaje: análisis predictivo de estudios en el desempeño académico de alumnos de bachillerato. Revista Mexicana de Psicología, 10, 63-73.

Maya A. (2003). La educación a distancia y la función tutorial. Costa rica: UNESCO-San José.

Montserrat, S. Gisbert, M. \& Isus, S. (2007). E-tutoría: uso de las tecnologías de la información y comunicación para la tutoría académica universitaria. Revista Electrónica Teoría de la Educación. Educación y Cultura en la Sociedad de la Información. http://gredos.usal.es/jspui/bitstream/10366/56560/1/TEE2007_V8N2_P116.pdf

Prado, J. \& García, I. (2009). La acción tutorial desde la perspectiva de los alumnos. España: Universidad de Salamanca.

Nájera, F. y García, M. (2007). El proceso de tutoría en la Escuela Normal de los Reyes; Representaciones y significados. Memorias en extenso del IX Congreso Nacional del Consejo Mexicano de Investigación Educativa, Noviembre, Mérida, Yucatán.

Navarro, E. (2003). El rendimiento académico: concepto, investigación y desarrollo. Revista Iberoamericana de Educación. Organización de Estados Iberoamericanos para la Educación, la Ciencia y la Cultura. Vol. 1

Rigalt, C. (s.f.). Presentación Semántica del tutor: Influencia del género y de los niveles de riesgo académico en estudiantes universitarios que asisten a tutoría. Primer Congreso Institucional de Investigación. Universidad del Valle de México. http://www.tlalpan.uvmnet.edu/oiid/download/Representación \%20semántica\%20tutor_04_CSO_PSIC_PICSJ_ D.pdf

Universidad de Guadalajara (2004). La tutoría académica y la calidad de la educación. http://148.202.105.12/tutoria/pdfc/C2.pdf

University Teaching Development Center. (2007). Tutor Survival Guiade 2007. A Guide for turor al Victoria University of Wellington. Viatoria: Univertity teachin Develpment Center, Victoria University of Wellinton.

Vales, J. (2009). Nuevas tecnologías para el aprendizaje. México: Pearson.

Vásquez, R., y Mejía, Y. (2008). Las Tutorías Electrónicas como complemento a las Presenciales. 3er Encuentro Nacional de Tutorías. Evaluar para Innovar. Puebla: Universidad Autónoma de Coahuila. 